\title{
NBL1 and anillin (ANLN) genes over-expression in pancreatic carcinoma
}

\author{
Marek Olakowski ${ }^{1}$, Tomasz Tyszkiewicz ${ }^{2}$, Michał Jarząb ${ }^{3}$, Robert Król ${ }^{4}$, \\ Małgorzata Oczko-Wojciechowska², Malgorzata Kowalska ${ }^{2}$, Monika Kowal'2, \\ Grzegorz M. Gala ${ }^{2}$, Maciej Kajor ${ }^{5}$, Dariusz Lange 6 , Ewa Chmielik', \\ Elzbieta Gubala ${ }^{2}$, Paweł Lampe ${ }^{1}$, Barbara Jarząb ${ }^{2}$
}

\author{
${ }^{1}$ Department of Digestive Tract Surgery, ${ }^{4}$ Department. of General, Vascular and Transplant Surgery, \\ ${ }^{5}$ Department of Pathomorphology, \\ Silesian Medical University, Katowice, Poland, \\ ${ }^{2}$ Department of Nuclear Medicine and Endocrine Oncology, ${ }^{3}$ Department of Clinical and Experimental \\ Oncology, Department of Tumor Biology, ${ }^{6}$ Department of Pathology, \\ Maria Skłodowska-Curie Memorial Cancer Center and Institute of Oncology, Gliwice, Poland
}

\begin{abstract}
The aim of the study was to analyze the gene expression profile of pancreatic cancer to derive novel molecular markers of this malignancy. The snap-frozen or RNA-later preserved samples of 18 pancreatic adenocarcinomas, 5 chronic pancreatitis cases and 6 specimens of grossly normal pancreas were used for microarray analysis by HG-U133 Plus 2.0 oligonucleotide Affymetrix arrays. Validation was carried out by real-time quantitative PCR (Q-PCR) in the set of 66 samples: 31 of pancreatic cancer, 14 of chronic pancreatitis and 21 of macroscopically unchanged pancreas. By Principal Component Analysis of the microarray data we found a very consistent expression pattern of normal samples and a less homogenous one in chronic pancreatitis. By supervised comparison (corrected p-value 0.001) we observed 11094 probesets differentiating between cancer and normal samples, while only seventy six probesets were significant for difference between cancer and chronic pancreatitis. The only gene occurring within the best 10 genes in both comparisons was S100 calcium binding protein P (S100P), already indicated for its utility as pancreatic cancer marker by earlier microarray-based studies. For validation we selected two genes which appeared as valuable candidates for molecular markers of pancreatic cancer: neuroblastoma, suppression of tumorigenicity 1 (NBL1) and anillin (ANLN). By Q-PCR, we confirmed statistically significant differences in these genes with a 9.5 fold-change difference between NBL1 expression in cancer/normal comparison and a relatively modest difference between cancer and pancreatitis. For ANLN even more distinct differences were observed (cancer/normal 19.8-fold, cancer/pancreatitis 4.0-fold). NBL1 and anillin are promising markers for pancreatic carcinoma molecular diagnostics.
\end{abstract}

Key words: pancreatic cancer, oligonucleotide microarrays, real-time quantitative PCR, NBL1 gene, anillin (ANLN) gene

\section{Introduction}

Due to its occurrence and poor prognosis, pancreatic cancer is the malignancy which takes the large death toll. Five-year survival rate approaches $25 \%$ if the

Correspondence: B. Jarząb, Dept. of Nuclear Medicine and Endocrine Oncology, Maria Skłodowska-Curie Memorial Cancer Center and Institute of Oncology, Wybrzeze Armii Krajowej 15, 44-101 Gliwice, Poland; tel.: (+4832) 2789301, fax.: (+4832) 2789325, e-mail bjarzab@io.gliwice.pl tumor is not advanced and can be surgically removed, otherwise it is only $5 \%$. Only $10 \%$ of patients are diagnosed with the early-stage resectable disease [1].

Early detection is one of the clues for the improvement in survival of pancreatic cancer patients. Until now, there is no reliable screening method, moreover, the diagnostic process is of limited performance. Imaging modalities like helical computed tomography, magnetic resonance imaging or endoscopic ultrasound have the sensitivity up to $95 \%$ in detection of small 
tumors, but the discrimination between benign and malignant masses is often very difficult. Fine needle aspiration biopsy is only between $50-70 \%$ accurate in determining whether the tumor is benign or malignant. There are two reasons limiting the efficiency of fine needle aspiration: sampling of tumor by the needle and the sensitivity of pathological examination of the specimen. The latter aspect could be significantly improved by either 1) introducing immunohistochemical markers to aid the diagnosis of pathologist or 2) supporting the pathological review by multi-gene measurement. The most probable is merging of both approaches, but until now it was limited by the insufficient accuracy of existing protein markers and relative paucity of multi-gene classifiers, able to efficiently discriminate low number of cells in regard to their malignancy.

Both the improvement of the efficacy of pathologist and the creation of complex diagnostic tests for pancreatic cancer rely on the powerful molecular markers. Until now, several microarray experiments have been carried out to analyze differences between the transcriptome of pancreatic cancer and benign diseases (summarized in [2-4]). Still, these analyses did not result in any major progress in clinical diagnostics of pancreatic cancer, probably due to the relative insufficiency of the existing molecular markers. Some of the genomic profiling studies were carried out by early generation of microarrays; also, not always the technical drawbacks have been omitted. Even more difficult than in other cancers, obtaining of good quality RNA from pancreatic tissue, especially normal pancreas, is often compromised by the high activity of pancreatic enzymes and the resulting large RNA degradation.

The real power of microarray analyses will appear if several studies carried out independently by different groups lead to the specification of the panel of consensus markers. The aim of the present study, based on gene expression profiling, was to delineate novel molecular markers for pancreatic carcinoma, suitable for further diagnostic applications.

\section{Materials and methods}

Tissues samples. In gene expression measurements we used snapfrozen or RNA-later preserved samples collected from 66 patients operated on in Dept. of Digestive Tract Surgery of Silesian Medical University, among them $61 \%$ males and 39\% females. Within this group there were 31 patients with pancreatic cancer and 14 patients with chronic pancreatitis. In 21 patients macroscopically unchanged pancreatic tissue (normal or adjacent to diseased region) was collected.

RNA samples. Total RNA was isolated from approx. 30-50 mg of sample by Chomczynski-Sacchi method, followed by RNA cleanup on RNeasy Mini columns (Qiagen).

Microarray preparation and analysis. For microarray investigation, samples of the best RNA quality, as assessed by Agilent 2100
Bioanalyzer, were used: 18 pancreatic adenocarcinomas, 5 chronic pancreatitis cases and 6 specimens collected from microscopically unchanged pancreas. cDNA synthesis was carried out from $5 \mu \mathrm{g}$ of total RNA (GeneChip ${ }^{\circledR}$ Expression 3' Amplification One-Cycle cDNA Synthesis Kit, Affymetrix), then in vitro transcription was performed as described by microarray manufacturer (GeneChip ${ }^{\circledR}$ Expression 3' IVT Labeling Kit, Affymetrix). cRNA was hybridized to Human Genome U133 Plus 2.0 microarray, measuring approx. 38500 human transcripts (Affymetrix). Arrays were scanned in GeneChip Scanner 3000 (Affymetrix). The whole procedure was carried out according to the manufacturer's protocol. The obtained dataset was pre-processed using GC-RMA method. Unsupervised data-mining was carried out by Principal Component Analysis method (GeneSpring, Agilent). Gene selection was carried out by class comparison method, as implemented in limma Bioconductor package (with Benjamini-Hochberg False Discovery Rate estimation) [5].

RT-PCR. For real-time quantitative PCR (Q-PCR) cDNA synthesis was carried from $1 \mu \mathrm{g}$ of total RNA (Omniscript, Qiagen), the reaction was performed on Applied Biosystems SDS 7700 machine with Universal Probe Library fluorescent probes (Roche), with amplicon design done by web application provided by manufacturer. We analyzed four reference genes: ATP6V1E1, EIF3S10, HADHA, UBE2D2 and normalized the obtained result to the reference index obtained by geNorm software [6].

Ethical issues. All samples were collected upon approval by Ethics Committee of Silesian Medical University.

Statistical analysis. Expression data were analyzed by Statistica 6.0 package (Statsoft) by non-parametric Kruskall-Wallis test.

\section{Results}

We performed unsupervised assessment of the microarray dataset by Principal Component Analysis method (see Fig. 1A and 1B). We have found that the major source of variability is the difference between cancer and normal specimens (not shown). When the analysis was carried out only on cancer and normal samples, the cluster of normal pancreas showed a very homogenous pattern of expression, clearly delineating itself within the first Principal Component (Fig. 1A). Unsupervised analysis of cancer samples and chronic pancreatitis specimens showed much less homogeneity within chronic pancreatitis group, and much smaller distance between the two clusters (Fig. 1B). Moreover, the difference between pancreatic cancer and chronic pancreatitis did not allow to classify these two groups based on the first Principal Component; it was necessary to use two major sources of variability to differentiate between both classes.

In the next step, we carried out the supervised comparison of gene expression between normal samples of pancreatic tissue and tumor samples from patients with pancreatic cancer. We noticed a very large number of differentiating genes: from 54675 probesets on HGU133 Plus 2.0 microarray, 29208 of them showed corrected p-value below 0.05 . More than 11000 probesets were found to exhibit difference of high significance, 

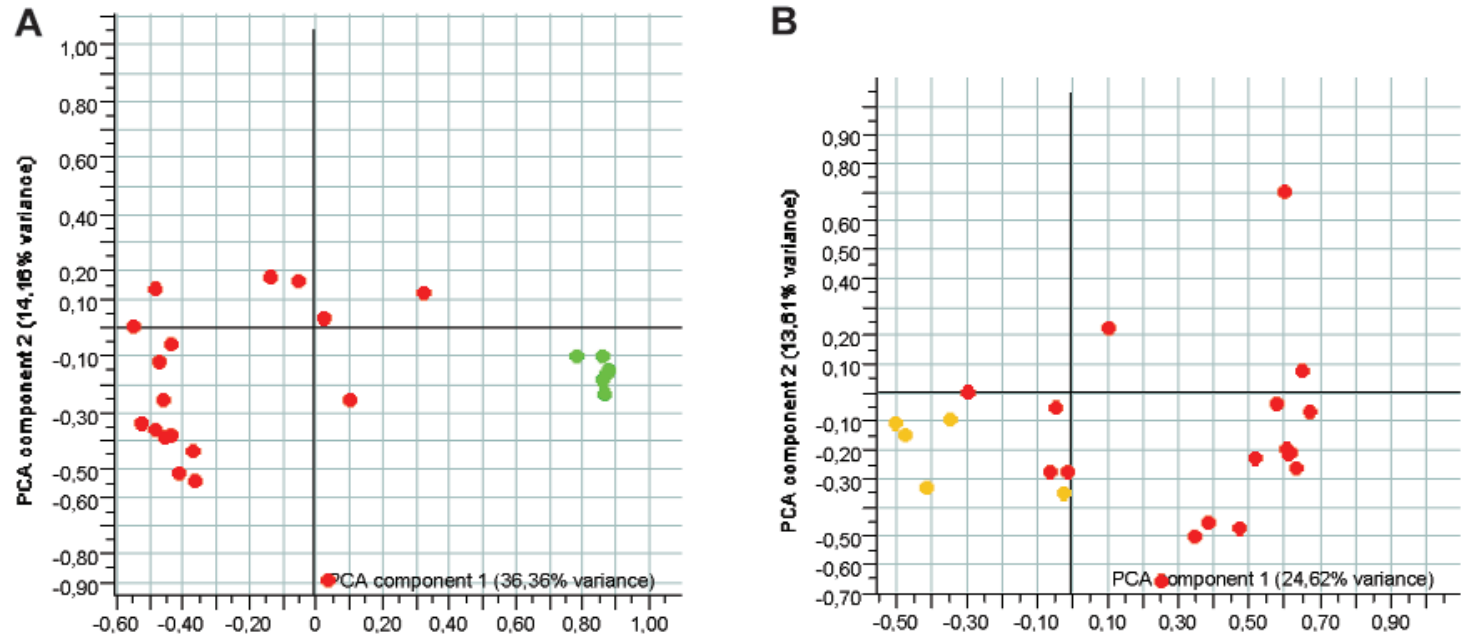

Fig. 1 Principal Components Analysis of pancreatic cancer (red) vs normal pancreas (green, Fig. 1A) and pancreatic cancer vs chronic pancreatitis (yellow, Fig. 1B). First two principal components are shown on X and Y axes.

with corrected p-value lower than 0.001 . Three most significant genes were found with false discovery rate approx. $10^{-15}$, confirming the high reliability of observed differences in gene expression (Table 1).

Comparison between pancreatic cancer and samples from patients with chronic pancreatitis resulted in the lower number of significant probesets. The limit of corrected p-value of 0.05 was met by 1332 transcripts. Seventy six of them showed corrected $p$ value $<0.001$, with three most significant transcripts at similar level of significance like in cancer-normal comparison $\left(10^{-15}\right)$ (Table 2). The results obtained in supervised approach were consistent with the unsupervised analysis: chronic pancreatitis samples were much more similar to pancreatic cancer, while the difference between cancer and normal pancreas was of very large magnitude.

The genes most over-expressed in cancer, compared to normal pancreas tissue, were collagen, type I, alpha 1 (signal $\log$ ratio SLR 3.99, i.a. more than 15fold increase), S100 calcium binding protein P (SLR 8.97, more than 500-fold increase), periostin (SLR 8.16), neuroblastoma, suppression of tumorigenicity 1 (NBL1, SLR 5.12, 34.7-fold increase in cancer), cofilin 1 (non-muscle) and S100 calcium binding protein A6 (calcyclin, SLR 5.08).

Among transcripts down-regulated with high significance in cancer in comparison to normal pancreas there was the most significant gene obtained in this comparison, coiled-coil domain containing 110, with 22-fold decrease of expression, cyclin-dependent kinase 2-interacting protein and one less characterized transcript.

The analysis of genes differentiating between pancreatic cancer and chronic pancreatitis pointed out the S100P, the only gene occurring within the first 10 transcripts in both comparisons and most significantly over-expressed in cancer when compared to pancreatitis specimens. More than 370-fold increase of S100P expression in pancreatic cancer versus chronic pancreatitis is of similar range like the one observed in comparison to normal specimens. The remaining genes showed a lower signal $\log$ ratio values, ranging from 4.88 for SERPINB5 (serpin peptidase inhibitor, clade $\mathrm{B}$, member 5) to 2.94 for KCNN4 (potassium intermediate/small conductance calcium-activated channel, subfamily N, member 4). Only one of selected genes (ADH1A, alcohol dehydrogenase 1A, alpha polypeptide) was down-regulated in cancer, when compared to chronic pancreatitis.

Two genes were selected for validation by quantitative real-time PCR: neuroblastoma, suppression of tumorigenicity 1 (NBL1) and anillin (ANLN). For both genes we confirmed the statistically significant differences in gene expression between pancreatic cancer, chronic pancreatitis and normal pancreas $(\mathrm{p}<0.0001$, Kruskall-Wallis ANOVA), for data normalized by geNorm (Table 3 and 4) and also for raw, unnormalized data (not shown). There was large, 9.5fold change difference between NBL1 expression in cancer/normal comparison, while the observed difference between cancer and pancreatitis was of low foldchange and of large overlap in gene expression (Fig. 2). For ANLN a gradual increase in expression from normal samples by chronic pancreatitis to large values in pancreatic cancer was observed (cancer/normal 19.8-fold, cancer/pancreatitis 4.0 -fold). In post-hoc inter-group comparisons, both genes differentiated between cancer/normal $(p<0.000001)$ and cancer/pancreatitis $(p<0.000001$ for ANLN and $p=0.000001$ for NBL1); for NBL1 there was also a moderate difference between normal specimens and pancreatitis $(\mathrm{p}=0.02)$, while for ANLN there was no significant dif- 
Table 1. Pancreatic cancer vs normal pancreas 10 top differentiating genes, based on microarray results.

\begin{tabular}{|c|c|c|c|c|c|c|c|}
\hline $\begin{array}{l}\text { Gene } \\
\text { symbol }\end{array}$ & Gene name & Alfy probe ID) & $\begin{array}{l}\text { Average } \\
\text { expression } \\
(\Lambda)\end{array}$ & $\begin{array}{l}\text { Signal log } \\
\text { ratio }(\mathrm{M})\end{array}$ & $\begin{array}{l}\text { t test } \\
\text { statistic }\end{array}$ & Pvalue & Limma $B$ \\
\hline CCDC 110 & $\begin{array}{l}\text { coiled-coil domain } \\
\text { containing } 110\end{array}$ & 230900_at & 3.71 & -4.49 & -25.37 & $1.40 \mathrm{E}-15$ & 35.13 \\
\hline COLlAl & $\begin{array}{l}\text { collagen, type I, alpha } \\
1\end{array}$ & 1556499_s_at & 12.10 & 3.99 & 23.55 & $4.76 \mathrm{E}-15$ & 33.50 \\
\hline S100P & $\begin{array}{l}\text { S100 calcium binding } \\
\text { protein } \mathrm{P}\end{array}$ & 204351_at & 8.14 & 8.97 & 22.80 & 7.27E-15 & 32.78 \\
\hline ALB & Albumin & 214842_s_at & 2.96 & -3.19 & -21.55 & $2.31 \mathrm{E}-14$ & 31.52 \\
\hline CINP & $\begin{array}{l}\text { Cyclin-dependent } \\
\text { kinase 2-interacting } \\
\text { protein }\end{array}$ & 239225_at & 2.77 & -1.44 & -17.82 & $1.85 \mathrm{E}-12$ & 27.19 \\
\hline ВC015783 & $\begin{array}{l}\text { Homo sapiens, clone } \\
\text { IMAGE: } 4857346, \\
\text { mRNA }\end{array}$ & 1570430_at & 3.44 & -2.26 & -17.82 & $1.85 \mathrm{E}-12$ & 27.19 \\
\hline POSTN & $\begin{array}{l}\text { periostin, osteoblast } \\
\text { specific factor }\end{array}$ & 210809_s_at & 9.34 & 8.16 & 17.08 & $4.51 \mathrm{E}-12$ & 26.21 \\
\hline NBLl 1 & $\begin{array}{l}\text { neuroblastoma, } \\
\text { suppression of } \\
\text { tumorigenicity } 1\end{array}$ & 37005_at & 7.81 & 5.12 & 16.75 & $6.41 \mathrm{E}-12$ & 25.76 \\
\hline CFLl & $\begin{array}{l}\text { cofilin } 1 \\
\text { (non-muscle) }\end{array}$ & 200021_at & 12.10 & 1.68 & 16.62 & $6.90 \mathrm{E}-12$ & 25.58 \\
\hline $\mathrm{S} 100 \wedge 6$ & $\begin{array}{l}\text { S100 calcium binding } \\
\text { protein } \Lambda 6 \text { (calcyclin) }\end{array}$ & 217728_at & 11.22 & 5.08 & 16.45 & $7.94 \mathrm{~F}-12$ & 25.35 \\
\hline
\end{tabular}

Table 2. Pancreatic cancer vs chronic pancreatitis 10 top differentiating genes, based on microarray results.

\begin{tabular}{|c|c|c|c|c|c|c|c|}
\hline $\begin{array}{c}\text { Gene } \\
\text { symbol }\end{array}$ & Gene name & $\begin{array}{l}\text { Affy Probe } \\
\text { ID }\end{array}$ & $\begin{array}{l}\text { Average } \\
\text { expression } \\
\text { (A) }\end{array}$ & $\begin{array}{c}\text { Signal Log } \\
\text { Ratio (M) }\end{array}$ & $\begin{array}{c}\text { t test } \\
\text { statistic }\end{array}$ & $P$ value & Limma B \\
\hline S100P & $\begin{array}{l}\text { S100 calcium binding } \\
\text { protein } \mathrm{P}\end{array}$ & 204351_at & 8.14 & 8.54 & 20.24 & $4.51 \mathrm{E}-13$ & 26.10 \\
\hline SERPINB5 & $\begin{array}{l}\text { serpin peptidase inhibitor, } \\
\text { clade B (ovalbumin), } \\
\text { member } 5\end{array}$ & 204855_at & 5.60 & 4.88 & 11.20 & $3.36 \mathrm{~F}-07$ & 15.63 \\
\hline RDHE2 & NA & 238017_at & 6.08 & 4.52 & 8.87 & $3.26 \mathrm{E}-05$ & 11.35 \\
\hline ANLN & $\begin{array}{l}\text { anillin, actin binding protein } \\
\text { (scraps homolog, } \\
\text { Drosophila) }\end{array}$ & 222608_s_at & 5.25 & 3.28 & 8.69 & 3.54E-05 & 10.98 \\
\hline GPRC5 4 & $\begin{array}{l}\text { G protein-coupled receptor, } \\
\text { family } \mathrm{C} \text {, group } 5 \text {, member } \\
\text { A }\end{array}$ & 203108_at & 7.95 & 3.95 & 8.55 & $3.54 \mathrm{E}-05$ & 10.67 \\
\hline KCNN4 & $\begin{array}{l}\text { potassium intermediate/ } \\
\text { small conductance calcium- } \\
\text { activated channel, subfamily } \\
\mathrm{N} \text {, member } 4\end{array}$ & 204401_at & 5.92 & 2.94 & 8.54 & $3.54 \mathrm{E}-05$ & 10.66 \\
\hline PI.FK2 & pleckstrin 2 & 218644_at & 6.09 & 3.06 & 8.31 & $5.18 \mathrm{~F}_{-}-05$ & 10.18 \\
\hline FAM108C1 & $\begin{array}{l}\text { family with sequence } \\
\text { similarity } 108 \text {, member } \mathrm{Cl}\end{array}$ & 225436_at & 6.71 & 3.38 & 8.15 & $6.61 \mathrm{E}-05$ & 9.84 \\
\hline ADH1A & $\begin{array}{l}\text { alcohol dehydrogenase } 1 \mathrm{~A} \\
\text { (class I), alpha polypeptide }\end{array}$ & 207820_at & 3.14 & -0.74 & -8.02 & $7.65 \mathrm{E}-05$ & 9.57 \\
\hline TOP2A & $\begin{array}{l}\text { topoisomerase (DNA) II } \\
\text { alpha } 170 \mathrm{kDa}\end{array}$ & 201291_s_at & 6.01 & 3.38 & 7.99 & $7.65 \mathrm{E}-05$ & 9.50 \\
\hline
\end{tabular}


Table 3. Comparison between normal $(\mathrm{N})$, chronic pancreatitis $(\mathrm{P})$ and cancer samples from pancreatic carcinoma $(\mathrm{T})$ by real-time quantitative PCR for ANLN and NBL1 gene. Mean, median and quartile values are given. Presented data are absolute, given in relation to the expression of both genes in Stratagene Reference Total RNA, after normalization by geNorm-obtained index (expression of 1 is equal to the expression of each gene in reference RNA).

\begin{tabular}{|l|c|c|c|c|c|c|c|c|c|c|c|c|}
\hline & \multicolumn{4}{|c|}{ Mean } & \multicolumn{4}{c|}{ Median } & \multicolumn{3}{c|}{ Lower quartile (Q25) } & \multicolumn{3}{c|}{ Upper quartile (Q75) } \\
\cline { 2 - 13 } & $\mathrm{N}$ & $\mathrm{P}$ & $\mathrm{T}$ & $\mathrm{N}$ & $\mathrm{P}$ & $\mathrm{T}$ & $\mathrm{N}$ & $\mathrm{P}$ & $\mathrm{T}$ & $\mathrm{N}$ & $\mathrm{P}$ & $\mathrm{T}$ \\
\hline$\Lambda$ NL,N & 0.01 & 0.05 & 0.21 & 0.01 & 0.04 & 0.20 & 0.01 & 0.02 & 0.11 & 0.01 & 0.05 & 0.27 \\
\hline NBI,1 & 0.18 & 1.11 & 1.72 & 0.13 & 1 & 1.37 & 0.07 & 0.36 & 0.91 & 0.21 & 1.51 & 1.91 \\
\hline
\end{tabular}

A

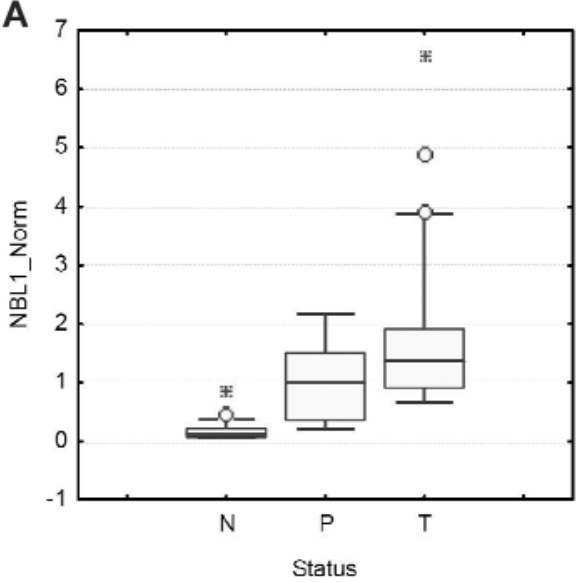

B

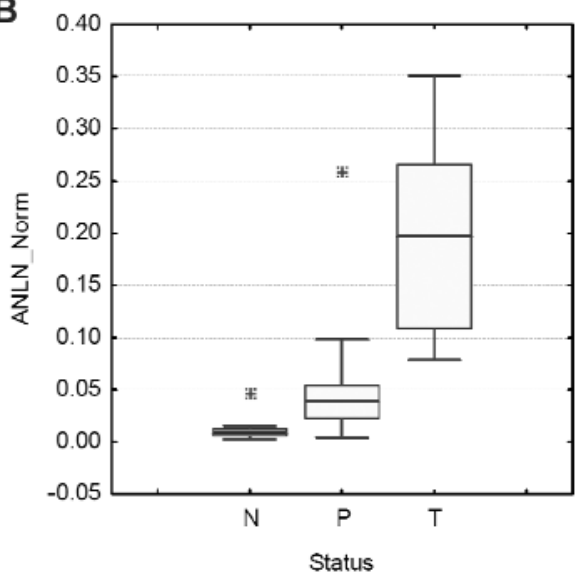

Fig. 2 Quantitative real-time PCR measurement of gene expression for NBL1 (A) and ANLN (B) genes in normal pancreas $(\mathrm{N})$, chronic pancreatitis $(\mathrm{P})$ and cancer sample $(\mathrm{T})$ from patients with pancreatic cancer. Values
Table 4. Comparison between normal, chronic pancreatitis and cancer samples from pancreatic carcinoma by real-time quantitative PCR for ANLN and NBL1 gene. Ratios of mean values are presented.

\begin{tabular}{|l|c|c|c|}
\hline \multirow{2}{*}{} & \multicolumn{3}{|c|}{ Fold change } \\
\cline { 2 - 4 } & $\begin{array}{c}\text { Cancer } \boldsymbol{v} s \\
\text { nomal }\end{array}$ & $\begin{array}{c}\text { Cancer } \boldsymbol{v} s \\
\text { pancreatitis }\end{array}$ & $\begin{array}{c}\text { Pancreatitis } v \boldsymbol{s} \\
\text { nommal }\end{array}$ \\
\hline ANLN & 19.79 & 4.00 & 4.95 \\
\hline NBLl & 9.5 & 1.55 & 6.13 \\
\hline
\end{tabular}

ference between these two groups, probably due to low number of samples in both groups, with moderate fold change.

\section{Discussion}

In our study we analyzed differences in gene expression between pancreatic cancer, chronic pancreatitis, the important benign disease often mimicking clinically pancreatic carcinoma, and normal pancreas tissue. In our opinion it is very important to base the marker selection process on both comparisons, as the first one is the most often occurring in clinical setting, while the second one is very important from the point of view of potential inappropriate sampling. Its inclusion allows the correct discrimination of normal pancreas which may be erroneously obtained during the diagnostic process.
The comparison of both gene lists, the one obtained for pancreatic cancer vs normal pancreas and the other obtained for pancreatic cancer vs chronic pancreatitis, revealed within the top differentiating transcripts only one common gene, S100P. This gene has been indicated by Logsdon et al for its gene expression up-regulation in pancreatic cancer already in 2003 [7]. Further studies have indicated that it is up-regulated mainly in pancreatic cancer cells, early in pancreatic cancerogenesis and may be applied in the immunohistochemical diagnostics (8-11).

Looking for novel markers, for further validation we selected two genes: NBL1, optimally differentiating pancreatic cancer from normal pancreas, and anillin which appeared as a potential good marker differentiating between chronic pancreatitis and cancer. The obtained results lead to the conclusion that especially anillin is a very good discriminator for both groups.

Anillin gene (HUGO name: anillin, actin binding protein, abbreviated ANLN, also known as Drosophila Scraps homolog, DKFZp779A055), located on chromosome $7 \mathrm{p} 14.2,84 \mathrm{~kb}$ in length, is transcribed from 24 exons, with 20 splice variants (reference transcript NM_018685.2). It encodes 1124 aminoacid protein with estimated molecular weight $123 \quad 477$ (NP_061155.2, UniProt/Swiss-Prot Q9NQW6). During interphase, anillin is preferentially localized in the cell nucleus, in anaphase it concentrates to form the contractile ring. It interacts with $\mathrm{F}$-actin and regulates 
the contractile activity of myosin II. It is required for cytokinesis as an essential element of cleavage furrow formation, and suggested to be a pivotal organizer of the cytokinetic machinery [12].

Anillin is a gene expressed at the highest levels in brain, but rather ubiquitously present in various tissues. It is present in developing and in mature organs. As its expression is highly increased in dividing cells (it is present in mitosis and during $\mathrm{S}$ and $\mathrm{G} 2$ phases, low in G1 phase), some of its tissue specificity may be related to the tissue proliferative potential (high in placenta, testis, at intermediate level in intestine, ovary, thymus), but it may be in other way related to the function of cytoskeleton (very high in brain, moderate expression in skeletal muscles).

Anillin gene has been found to be over-expressed in breast tumors [13], endometrial carcinomas [14] and gastric cancer [15]. Hall et al. [16] analyzed anillin expression by electronic northern blot and oligonucleotide microarrays in a huge dataset of more than 7 thousand samples and found that anillin mRNA level was higher in cancers than normal tissues, with moderate correlation to Ki67 gene expression. They also found that anillin expression showed a tumor progression-related pattern of expression in breast, ovarian, kidney, colorectal, hepatic, lung, endometrial and pancreatic cancer.

Simultaneously, an over-expression of ANLN was found to be associated with pulmonary carcinogenesis [17], based on earlier gene expression data for lung cancer [18], and it has been experimentally demonstrated that anillin expression is related to disease aggressiveness by interaction with RhoA (small GTPase acting as a key regulator of contractile-ring formation during cytokinesis, and known to directly interact with anillin [19]). By immunohistochemistry the authors demonstrated the association of ANLN expression with the poor survival in non-small cell lung cancer. This was further confirmed by Skrzypski et al. (20), who assessed ANLN expression in early-stage lung cancer.

NBL1 gene (NM_005380.4, HUGO name: neuroblastoma, suppression of tumorigenicity 1 , also known as N03, DAN, DAND1, MGC8972 or D1S1733E), is located on chromosome 1p36.13. It was identified as a putative tumor suppressor gene in transformed fibroblasts model and was mapped to the putative neuroblastoma tumor suppressor locus [21,22].

It encodes 180 aminoacid secreted protein (NP_005371.1) which is bone morphogenetic proteins antagonist, blocking BMP interaction with their receptors. NBL1 was able to stimulate differentiation of neuroblastoma cells in culture in the presence of retinoic acid [23]. The growth suppressive activity has been also noted in sarcoma cells [24], later on it has been shown that NBL1 is engaged in osteoblast differentation [25].
NBL1-mediated antagonism of Bmp pathway in mice is important for brain development (26). In pituitary gonadotrope cells, NBL1 is stimulated by GnRH [27]; it inhibits monocyte chemotaxis in vitro (28). In dorsal root ganglia of rat, it may act as neurotransmitter [29].

The fact that previously NBL1 has been attributed the role of tumor suppressor in neuroblastoma somewhat contradicts our observations that it is highly overexpressed in pancreatic cancer. However, its role in neuroblastoma seems to be controversial: it was excluded based on $\mathrm{LOH}$ analysis [30] and more recent data of the same group point out other more probable candidates in the same chromosomal region [31,32].

While anillin has been listed by Hall et al. [14] as the potential marker in pancreatic carcinoma, NBL1 has not gained any focused attention in this context up to now. Both genes were listed by landmark studies of Iacobuzio-Donahue: NBL1 from cDNA platform analysis [33] while ANLN in the study integrating oligonucleotide, cDNA and SAGE analysis [34]. However, from that time they were not further investigated. Our results indicate that both of them are good candidates for further studies as markers of pancreatic malignancy and simultaneuously point out on anillin for its potential to discriminate between cancer both from normal pancreas and chronic pancreatitis. We consider that the occurrence of both genes in two independent microarray datasets, supported by the RNA level Q-PCR validation should be a rationale to use them as RNA markers independently from the further (necessary) confirmation of their diagnostic usefullness by immunohistochemistry.

Acknowledgements: Research presented in this study was funded by a grant of Polish Ministry of Science and Higher Education no. 2 P05C 02526 to M.O.

\section{References}

[ 1] Schneider G, Siveke JT, Eckel F, Schmid RM. Pancreatic cancer: basic and clinical aspects. Gastroenterology. 2005;128(6):1606-1625.

[ 2] Grutzmann R, Boriss H, Ammerpohl O, Luttges J, Kalthoff H, Schackert HK et al. Meta-analysis of microarray data on pancreatic cancer defines a set of commonly dysregulated genes. Oncogene. 2005;24(32):5079-5088.

[3] Chelala C, Hahn SA, Whiteman HJ, Barry S, Hariharan D, Radon TP et al. Pancreatic Expression database: a generic model for the organization, integration and mining of complex cancer datasets. BMC Genomics. 2007;8:439.

[4] Garcea G, Neal CP, Pattenden CJ, Steward WP, Berry DP. Molecular prognostic markers in pancreatic cancer: a systematic review. Eur J Cancer. 2005;41(15):2213-2236.

[ 5] Wettenhall JM, Smyth GK. limmaGUI: a graphical user interface for linear modeling of microarray data. Bioinformatics. 2004;20(18):3705-3706.

[ 6] Vandesompele J, De PK, Pattyn F, Poppe B, Van RN, De PA et al. Accurate normalization of real-time quantitative RTPCR data by geometric averaging of multiple internal control genes. Genome Biol. 2002;3(7):RESEARCH0034. 
[ 7] Logsdon CD, Simeone DM, Binkley C, Arumugam T, Greenson JK, Giordano TJ et al. Molecular profiling of pancreatic adenocarcinoma and chronic pancreatitis identifies multiple genes differentially regulated in pancreatic cancer. Cancer Res. 2003;63(10):2649-2657.

[ 8] Whiteman HJ, Weeks ME, Dowen SE, Barry S, Timms JF, Lemoine NR et al. The role of S100P in the invasion of pancreatic cancer cells is mediated through cytoskeletal changes and regulation of cathepsin D. Cancer Res. 2007;67(18):8633-8642.

[ 9] Ohuchida K, Mizumoto K, Egami T, Yamaguchi H, Fujii K, Konomi $\mathrm{H}$ et al. S100P is an early developmental marker of pancreatic carcinogenesis. Clin Cancer Res. 2006;12(18):5411-5416.

[10] Deng H, Shi J, Wilkerson M, Meschter S, Dupree W, Lin F. Usefulness of S100P in diagnosis of adenocarcinoma of pancreas on fine-needle aspiration biopsy specimens. Am J Clin Pathol. 2008;129(1):81-88.

[11] Lin F, Shi J, Liu H, Hull ME, Dupree W, Prichard JW et al. Diagnostic utility of S100P and von Hippel-Lindau gene product ( $\mathrm{pVHL}$ ) in pancreatic adenocarcinoma-with implication of their roles in early tumorigenesis. Am J Surg Pathol. 2008;32(1):78-91.

[12] Hickson GR, O'Farrell PH. Anillin: a pivotal organizer of the cytokinetic machinery. Biochem Soc Trans. 2008;36(Pt 3):439-441.

[13] Ma XJ, Salunga R, Tuggle JT, Gaudet J, Enright E, McQuary $\mathrm{P}$ et al. Gene expression profiles of human breast cancer progression. Proc Natl Acad Sci U S A. 2003;100(10):5974-5979.

[14] Moreno-Bueno G, Sanchez-Estevez C, Cassia R, RodriguezPerales S, az-Uriarte R, Dominguez $\mathrm{O}$ et al. Differential gene expression profile in endometrioid and nonendometrioid endometrial carcinoma: STK15 is frequently overexpressed and amplified in nonendometrioid carcinomas. Cancer Res. 2003;63(18):5697-5702.

[15] Chen X, Leung SY, Yuen ST, Chu KM, Ji J, Li R et al. Variation in gene expression patterns in human gastric cancers. Mol Biol Cell. 2003;14(8):3208-3215.

[16] Hall PA, Todd CB, Hyland PL, McDade SS, Grabsch H, Dattani $\mathrm{M}$ et al. The septin-binding protein anillin is overexpressed in diverse human tumors. Clin Cancer Res. 2005;11(19 Pt 1):6780-6786.

[17] Suzuki C, Daigo Y, Ishikawa N, Kato T, Hayama S, Ito T et al. ANLN plays a critical role in human lung carcinogenesis through the activation of RHOA and by involvement in the phosphoinositide 3-kinase/AKT pathway. Cancer Res. 2005;65(24):11314-11325.

[18] Kikuchi T, Daigo Y, Katagiri T, Tsunoda T, Okada K, Kakiuchi $\mathrm{S}$ et al. Expression profiles of non-small cell lung cancers on cDNA microarrays: identification of genes for prediction of lymph-node metastasis and sensitivity to anti-cancer drugs. Oncogene. 2003;22(14):2192-2205.

[19] Piekny AJ, Glotzer M. Anillin is a scaffold protein that links RhoA, actin, and myosin during cytokinesis. Curr Biol. 2008;18(1):30-36.

[20] Skrzypski M, Jassem E, Taron M, Sanchez JJ, Mendez P, Rzyman W et al. Three-gene expression signature predicts survival in early-stage squamous cell carcinoma of the lung. Clin Cancer Res. 2008;14(15):4794-4799.
[21] Ozaki T, Sakiyama S. Tumor-suppressive activity of N03 gene product in v-src-transformed rat $3 \mathrm{Y} 1$ fibroblasts. Cancer Res. 1994;54(3):646-648.

[22] Enomoto H, Ozaki T, Takahashi E, Nomura N, Tabata S, Takahashi $\mathrm{H}$ et al. Identification of human DAN gene, mapping to the putative neuroblastoma tumor suppressor locus. Oncogene. 1994;9(10):2785-2791.

[23] Nakamura Y, Ozaki T, Ichimiya S, Nakagawara A, Sakiyama S. Ectopic expression of DAN enhances the retinoic acidinduced neuronal differentiation in human neuroblastoma cell lines. Biochem Biophys Res Commun. 1998;243(3):722-726.

[24] Hanaoka E, Ozaki T, Nakamura Y, Moriya H, Nakagawara A, Sakiyama S. Overexpression of DAN causes a growth suppression in p53-deficient SAOS-2 cells. Biochem Biophys Res Commun. 2000;278(1):20-26.

[25] Shinbo J, Ozaki T, Nakagawa T, Watanabe K, Nakamura Y, Yamazaki M et al. p73-dependent expression of DAN during cisplatin-induced cell death and osteoblast differentiation. Biochem Biophys Res Commun. 2002;295(2):501-507.

[26] Kim AS, Pleasure SJ. Expression of the BMP antagonist Dan during murine forebrain development. Brain Res Dev Brain Res. 2003;145(1):159-162.

[27] Lopez de MR, Martin B, Millar RP, Brown P, Davidson L, Pawson AJ et al. GnRH-mediated DAN production regulates the transcription of the GnRH receptor in gonadotrope cells. Neuromolecular Med. 2007;9(3):230-248.

[28] Chen B, Blair DG, Plisov S, Vasiliev G, Perantoni AO, Chen $\mathrm{Q}$ et al. Cutting edge: bone morphogenetic protein antagonists Drm/Gremlin and Dan interact with Slits and act as negative regulators of monocyte chemotaxis. $J$ Immunol. 2004;173(10):5914-5917.

[29] Ohtori S, Yamamoto T, Ino H, Hanaoka E, Shinbo J, Ozaki T et al. Differential screening-selected gene aberrative in neuroblastoma protein modulates inflammatory pain in the spinal dorsal horn. Neuroscience. 2002;110(3):579-586.

[30] White PS, Maris JM, Beltinger C, Sulman E, Marshall HN, Fujimori $\mathrm{M}$ et al. A region of consistent deletion in neuroblastoma maps within human chromosome 1p36.2-36.3. Proc Natl Acad Sci U S A. 1995;92(12):5520-5524.

[31] Fujita T, Igarashi J, Okawa ER, Gotoh T, Manne J, Kolla V et al. CHD5, a tumor suppressor gene deleted from 1p36.31 in neuroblastomas. J Natl Cancer Inst. 2008;100(13):940-949.

[32] Okawa ER, Gotoh T, Manne J, Igarashi J, Fujita T, Silverman KA et al. Expression and sequence analysis of candidates for the $1 \mathrm{p} 36.31$ tumor suppressor gene deleted in neuroblastomas. Oncogene. 2008;27(6):803-810.

[33] Iacobuzio-Donahue CA, Maitra A, Olsen M, Lowe AW, van Heek NT, Rosty C et al. Exploration of global gene expression patterns in pancreatic adenocarcinoma using cDNA microarrays. Am J Pathol. 2003;162(4):1151-1162.

[34] Iacobuzio-Donahue CA, Ashfaq R, Maitra A, Adsay NV, Shen-Ong GL, Berg K et al. Highly expressed genes in pancreatic ductal adenocarcinomas: a comprehensive characterization and comparison of the transcription profiles obtained from three major technologies. Cancer Res. 2003;63(24):8614-8622.

Submitted: 2 January, 2009 Accepted after reviews: 11 February, 2009 